\title{
Insulin Release in Response to Oral Glucose in Obesity: The Effect of Reduction of Body Weight
}

\author{
P.C. Farrant, R.W.J. Neville and G.A. Stewart
}

The Dartford District Hospital and the Wellcome Biological Control Laboratories, Dartford, Kent, England

Received: August 16, 1968

\begin{abstract}
Summary. Measurements of plasma levels of immunoreactive insulin, non-esterified fatty acids and glucose have been made in normal subjects and a group of obese nondiabetic patients, before and after a period of dietary restriction. Levels of immuno-reactive insulin, both in the fasted state and after an oral glucose load, were abnormally high in the group of obese patients and were significantly lower after dietary restriction and loss of body weight.
\end{abstract}

Libération d'insuline en réponse à l'administration orale de glucose dans l'obésité: Elffet de la réduction du poids corporel

Résumé. La concentration plasmatique d'insuline immuno-réactive, d'acides gras non estérifiés et de glucose a été déterminée chez des sujets normaux et dans un groupe d'obèses non diabétiques avant et après une période de restriction alimentaỉre. La concentration d'insuline immuno-réactive à jeun et après administration orale de glucose était anormalement élevée dans le groupe des sujets obèses et montra une diminution significative après une période de restriction alimentaire ayant entraîné une perte de poids.

Insulinfreisetzung unter oraler Glucosebelastung bei Fettsucht: Einfuß der Gewichtsabnahme

Zusammenfassung. Es wurden Messungen der Plasmaspiegel von immunreaktivem Insulin, unveresterten Fettsäuren und Glucose bei normalen Personen und bei einer Gruppe von fettleibigen Nichtdiabetikern vor sowie nach einer Periode der Diätbeschränkung vorgenommen. Die Konzentration des immunreaktiven Insulins lag bei den fettleibigen Patienten sowohl im Nüchternzustand als auch nach einer oralen Glucosebelastung abnorm hoch und ging nach Diätbeschränkung und Gewichtsverlust wesentlich zurück.

Key-words: Insulin levels, obesity, weight reduction.
Measurement of the level of insulin in plasma has shown that human obesity is associated with hyperinsulinism (KARAM et al., 1963). BUTTERFIELD, HANLEY and WHIOHELOW (1965) have shown that there is an inverse relationship between peripheral uptake of glucose and obesity, as measured by skin fold thickness. The effect of loss of weight on the levels of plasma insulin found in obese subjects has been little studied. The following investigation was therefore carried out to determine whether the rate of loss of body weight of an obese patient during a period of dieting was related. to the patient's initial body weight, to determine whether weight reduction was accompanied by changes in the plasma fasting levels of immuno-reactive insulin (IRI) glucose and non-esterified fatty acids (NEFA), and whether changes in these three parameters follow- ing a glucose load were modified after the period of dieting.

\section{Patients and Methods}

Twelve normal subjects and nine obese patients were studied. The latter were all referred to a medical clinic because of obesity, and were shown to have normal glucose tolerance. (Fasting venous blood glucose less than $110 \mathrm{mg} / 100 \mathrm{ml}$; venous blood glucose $1 \mathrm{~h}$ after $50 \mathrm{~g}$ of glucose by mouth less than $160 \mathrm{mg} / 100 \mathrm{ml}$, and $2 \mathrm{~h}$ after the oral dose less than $110 \mathrm{mg} / 100 \mathrm{ml}$.) Relevant data for the normal subjects and obese patients are shown in Table 1. One of the obese patients had moderate hypertension but the rest showed no clinical abnormality apart from obesity. All the obese patients adhered (with varying success) to a reducing diet which

Table 1. Personal details of subjects and patients

\begin{tabular}{|c|c|c|c|c|c|}
\hline Subjects & Sex & $\begin{array}{l}\text { Age range } \\
\text { (years) }\end{array}$ & $\begin{array}{l}\text { Weight ran- } \\
\text { ge (kg) }\end{array}$ & $\begin{array}{l}\text { Mean } \\
\text { weight (kg) }\end{array}$ & $\begin{array}{l}\text { Mean percent- } \\
\text { age of average } \\
\text { weight (Kems- } \\
\text { ley) }\end{array}$ \\
\hline $\begin{array}{l}\text { Normal } \\
\text { (12) }\end{array}$ & $\begin{array}{l}4 \mathrm{~F} \\
8 \mathrm{M}\end{array}$ & $17-60$ & $51-89$ & 71 & 105 \\
\hline $\begin{array}{l}\text { Obese } \\
(9)\end{array}$ & $6 \mathrm{~F}$ & $18-65$ & $83-159$ & 111 & 170 \\
\hline \multicolumn{2}{|c|}{$\begin{array}{l}\text { Obese after } \\
\text { weight reduction }\end{array}$} & & $72-103$ & 90 & 139 \\
\hline
\end{tabular}


in most instances varied in calorific value between 600 and $800 \mathrm{Kcals} / \mathrm{day}$. One obese patient received an acaloric diet for 7 weeks during the period of weight reduction, and during a period of 19 weeks lost $61 \mathrm{~kg}$ in weight. The remaining eight patients lost between 9 and $22 \mathrm{~kg}$ during periods of dietary restriction which varied from 15 to 39 weeks.

\section{Method of Investigation}

A standard oral glucose tolerance test was performed on all subjects and patients, and this was repeated after the period of dietary restriction. For two days prior to the first test all were receiving a diet containing at least $200 \mathrm{~g}$ of carbohydrate. For two days before the second test all continued to receive their reducing diet. The glucose tolerance test was performed after subjects and patients had fasted overnight; none was allowed to smoke on the day of the investigation. Venous blood samples were taken, using heparin as an anticoagulant, in the fasted state and at 15,30,60 and $120 \mathrm{~min}$ after an oral dose of $50 \mathrm{~g}$ glucose. Plasma was separated within the hour, and kept at $4^{\circ} \mathrm{C}$ until later in the day when it could be conveniently stored at $-10^{\circ} \mathrm{C}$. IRI was estimated in quadruplicate by the method of HaLES and RAINDLE (1963). Blood and plasma glucose were measured using a glucose oxidase method (FAULKNER, 1965) and plasma NEFA by a modification of a method of Trovt et al. (1960).

\section{Results}

In Fig. 1 are shown the mean levels of IRI both when fasting and after glucose in the normal subjects and the obese patients. Before dietary restriction mean
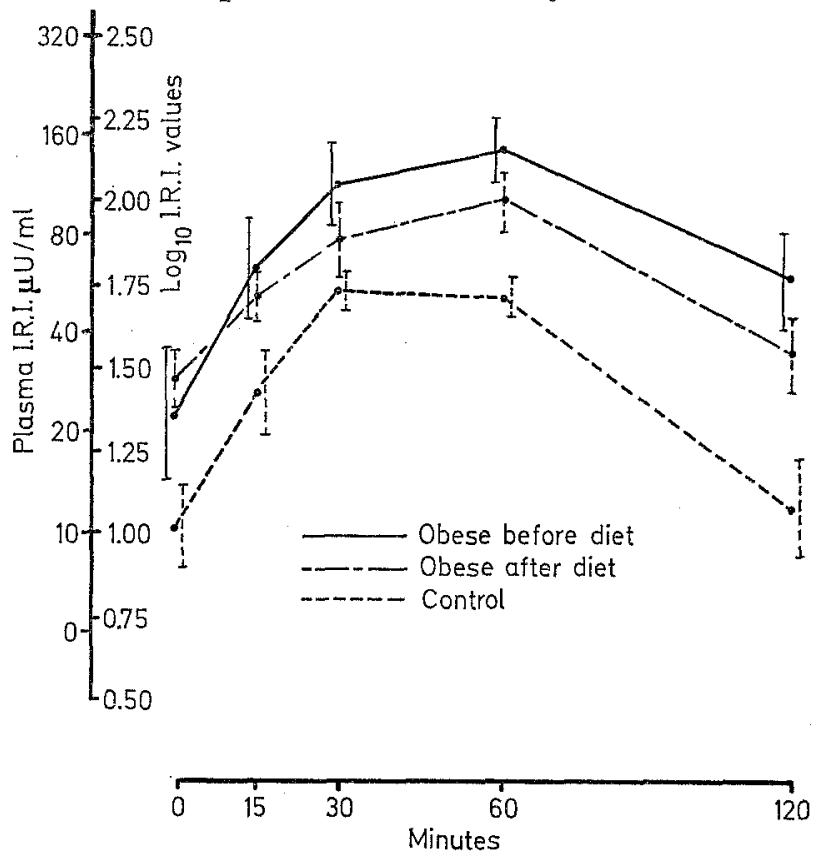

Fig. 1. Mean concentrations ( \pm S. E.) of plasma immunoreactive insulin after an oral glucose load in 12 normal subjects

(before diet levels of IRI in the obese patients were high at all sampling times, whereas after dieting there was a reduction in insulin output in response to glucose but no significant change in fasting levels. After dieting the mean level of IRI at $120 \mathrm{~min}$ was not significantly higher than the level found when fasting, whereas before dieting the mean level of IRI at $120 \mathrm{~min}$ exceeded the fasting level. The peak output of insulin in the case of the obese patients occured later than in the group of normal subjects. In Fig. 2 the mean levels for plasma glucose are shown and it is apparent that among the obese before dietary restriction there was a significant impairment of glucose tolerance. In Fig. 3 the mean increment

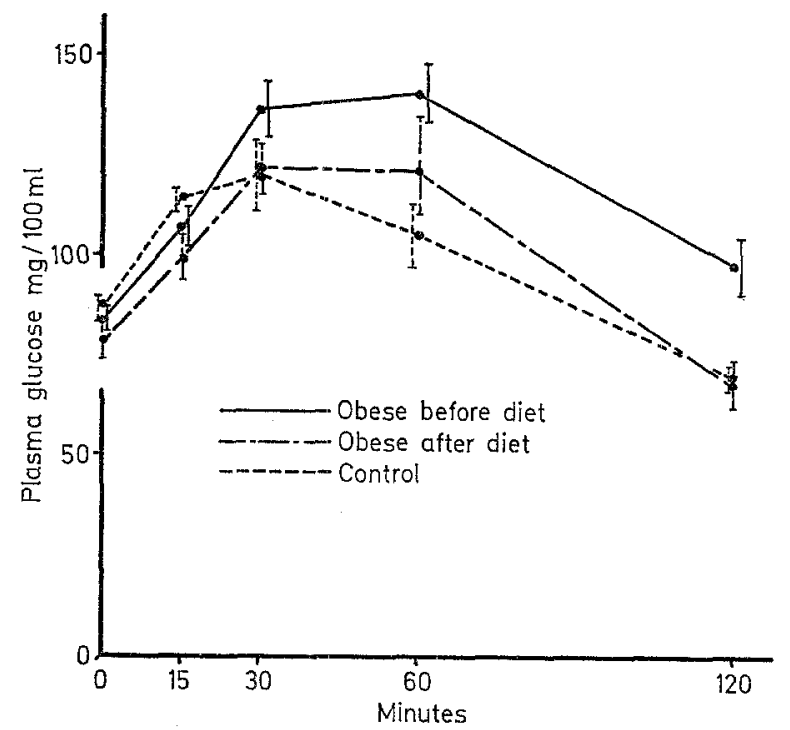

Fig. 2. Mean concentrations ( \pm S.E.) of plasma glucose after an oral glucose load. Normal subjects - $-\ldots$; Obese patients (before diet —— ; after diet $\bullet-\ldots-\cdots$ )

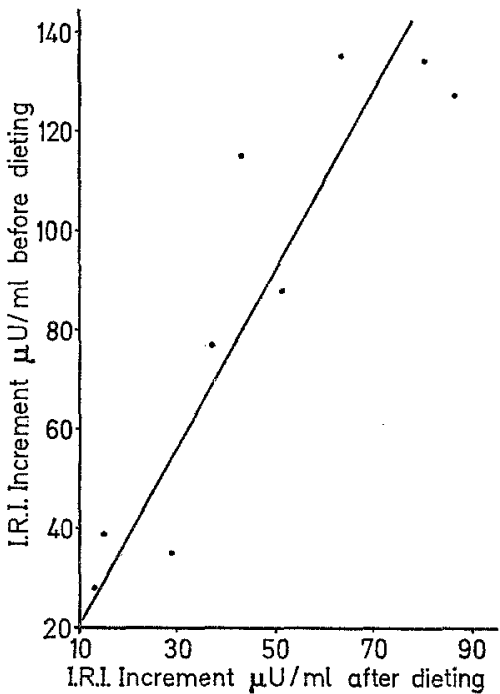

Fig. 3. Response of immuno-reactive insulin to oral glucose in obese non-diabetic patients before and after dieting (IRI increment derived by subtracting fasting value for IRI from value obtained at the other four sampling times, and taking the mean) 
of IRI after oral glucose has been plotted for each obese patient. The increment has been derived by subtracting the fasting value for IRI from the value obtained at the other four sampling times, and taking the mean. There is a linear relationship between the increment before and after dieting and from Fig. 3 it can be seen that the mean rise in IRI after dieting was only $55 \%$ of that present before dieting. Mean levels of NEFA (Table 2) were abnormally high at all sampling times in the obese patients before reduction of their weight. After. dieting there was a reduction in mean levels, but, this was only significant in the fasting and $30 \mathrm{~min}$ samples. lin, the plasma concentration of NEFA is reduced thus probably permitting glucose to be better utilised by muscle tissue. This study shows that with reduction of body weight, lower levels of IRI are found and the degree of insulin resistance is reduced. It is possible that if the obese state persists together with a high degree of insulin resistance, then impairment of the secretor mechanism for insulin could occur and diminished glucose tolerance would result.

Acknowledgement: We are indebted to Mr. F. W. HaRPLEY, B. Sc., A. I. S., for statistical help.

Table 2. Mean levels of non-esterified fatty acids in Subjects and Patients

\begin{tabular}{|c|c|c|c|c|c|}
\hline \multirow[b]{2}{*}{ Subjects } & \multicolumn{5}{|c|}{ Mean Levels of NEFA \pm S.E. $(\mathrm{mEq} / \mathrm{l})$} \\
\hline & Fasting & $15 \mathrm{~min}$ & $30 \mathrm{~min}$ & $60 \mathrm{~min}$ & $120 \min$ \\
\hline Normal (12) & $0.60 \pm 0.05$ & $0.60 \pm 0.07$ & $0.45 \pm 0.06$ & $0.37 \pm 0.06$ & $0.33 \pm 0.05$ \\
\hline Obese (9) & $0.80 \pm 0.05$ & $0.74 \pm 0.06$ & $0.73 \pm 0.07$ & $0.45 \pm 0.06$ & $0.46 \pm 0.10$ \\
\hline $\begin{array}{l}\text { Obese after weight } \\
\text { reduction (9) }\end{array}$ & $0.56 \pm 0.06$ & $0.75 \pm 0.12$ & $0.52 \pm 0.08$ & $0.36 \pm 0.07$ & $0.38 \pm 0.08$ \\
\hline
\end{tabular}

\section{Discussion}

Although dietary restriction has not altered the mean fasting levels of IRI in obese patients, it has caused a reduction in output of IRI in response to oral glucose. The mean levels of plasma glucose have been reduced to a smaller degree after dietary restriction, thus implying that there has been a reduction in the degree of insulin resistance. The results in Fig. 3 suggest that if the increment of IRI after glucose is more than twice the normal value, then dietary restriction will not reduce IRI levels to normality. GRODSkY (1967) however, has shown in a group of obese naval personnel that insulin levels usually revert to normal after dieting. No evidence is available as to the length of the period of dietary restriction necessary to reduce insulin levels in obese patients, nor whether this effect is due to carbohydrate restriction rather than loss of body weight. In acute starvation experiments it has been shown that starvation delays the time of appearance of the peak levels of IRI and does not reduce them (BECK et al., 1964).

The high level of plasma insulin found in obese human subjects may be due to the effects of high carbohydrate feeding or may be characteristic of the obese state itself. As the result of the high level of insu-

\section{References}

Beck, P., J.H.T. Kodmans, C.A. Wrnterling, M.F. Stein, W.H. Daughaday, and D.M. Krpnis: Studies of insulin and growth hormone secretion in human obesity. J. Lab. clin. Med. 64, 654-667 (1964).

Butterfieid, W.J.H., T. Hanley, and M.J. WhioheLOW: Peripheral metabolism of glucose and free fatty acids during oral glucose tolerance tests. Metabolism $14,851-866(1965)$.

FAULKNER, D.E.: An automated micro-determination of blood glucose with the auto-analyser. Analyst 90, $736-744(1965)$

Grodsky, G.M.: Personal communication (1967).

HALES, C.N., and P.J. RANDLE: Immunoassay of Insulin with Insulin-Antibody precipitate. Biochem. J. 88, 137-146 (1963).

Karam, J.H., G.M. Grodsky, and P.H. Forsham: Excessive insulin response to glucose in obese subjects as measured by immunochemical assay. Diabetes 12, 197-204 (1963).

Trour, D.L., E.H. Estes, Jnr., and S.J. Friedberg: Titration of free fatty acids of plasma : a study of current methods and a new modification. J. Lipid Res. 1, $199-202(1960)$.

P.C. Farraxt

R.W.J. NEVELLE

G.A. Stewart

The Datford District Hospital

and the Wellcome Biological

Control Laboratories

Dartford, Kent, England 